\title{
EFEKTIVITAS LATIHAN RANGE OF MOTION PADA PASIEN STROKE DI RUMAH SAKIT SITI HAJAR
}

\author{
EFFECTIVENESS OF RANGE OF MOTION EXERCISES IN STROKE \\ PATIENTS AT THE SITI HAJAR HOSPITAL \\ Anggriani $^{1}$, Nurul Aini ${ }^{2}$, Sulaiman*3 \\ 1,2,3 STIKes Siti Hajar \\ Jl. Letjen Jamin Ginting No. 2 Padang Bulan, Medan, Sumatera Utara \\ "Coresponding Author: ${ }^{1}$ anggriani.anggri1978@gmail.com; ${ }^{2}$ aini.nurul0205@yahoo.com ${ }^{* 3}$ sulaiman@ stikes-sitihajar.ac.id
}

\begin{abstract}
Abstrak
Prevalensi stroke terus bertambah seiring bertambahnya usia hidup. Penelitian ini dilakukan di Rumah Sakit Siti Hajar. Penelitian ini bertujuan untuk mengetahui sejauh mana efektifitas pemberian latihan ROM terhadap kekuatan Otot Ekstremitas pada Pasien Stroke. Desain penelitian ini dengan menggunakan quasi eksperimen dengan jumlah sampel 30 menggunakan one group pre-post desain. Tehnik pengambilan sampel secara purposif sampling. Analisa data menggunakan uji Wilcoxon Match Pairs. Terdapat peningkatan otot sesudah dilakukan intervensi sebesar 1.8, sedangkan kekuatan otot terjadi sampai dengan kondisi 5 (normal ) setelah dilakukan intervensi sebanyak $40 \%$.

Kata Kunci :Range of Motion, Stroke, Kekuatan Otot

Abstract

The prevalence of stroke continues to increase with age. This research was conducted at the Siti Hajar Hospital. This study aims to determine the effectiveness of ROM training on limb muscle strength in stroke patients. This research design using quasi-experimental with a sample size of 30 using one group pre-post design. The sampling technique was purposive sampling. Data analysis used the Wilcoxon Match Pairs test. There was an increase in muscle after intervention by 1.8, while muscle strength occurred up to condition 5 (normal) after intervention was $40 \%$.
\end{abstract}

Keywords: Range of Motion, Stroke, Muscle Strength

\section{PENDAHULUAN}

Stroke merupakan penyakit yang terjadi pada otak berupa gangguan fungsi syaraf lokal dan global, munculnya mendadak, progresif, dan cepat. Gangguan fungsi syaraf pada stroke 
Journal of Healthcare Technology and Medicine Vol. 6 No. 2 Oktober 2020

Universitas Ubudiyah Indonesia

e-ISSN : 2615-109X

disebabkan oleh gangguan perdarahan otak non traumatic yang menimbulkan gejala antara lain: kelumpuhan wajah atau anggota badan, bicara tidak lancer, bicara tidak jelas (pelo, mungkin perubahan kesadaran, gangguan penglihatan, dan lain-lain (Word Health Organization, 2014). Pengabdian yang dilakukan di Desa Hamparan Perak Kecamatan hamparan Perak ditemukan bahwa rata-rata lanjut usia di desa tersebut mengalami kasus stroke salah satunya adalah kurangnya latihan ROM yang diberikan pada lansia yang mengalami gangguan stroke. (Sulaiman, \& Anggriani, 2019)

Penderita stroke perlu penanganan yang baik untuk mencegah kecacatan fisik dan mental. Sebesar 30\% - 40\% penderita stroke dapat sembuh sempurna bila ditangani dalam waktu 6 jam pertama (golden periode), namun apabila dalam waktu tersebut pasien stroke tidak mendapatkan penanganan yang maksimal maka akan terjadi kecacatan atau kelemahan fisik seperti hemiparese. Penderita stroke post serangan membutuhkan waktu yang lama untuk memulihkan dan memperoleh fungsi penyesuaian diri secara maksimal. Terapi dibutuhkan segera untuk mengurangi cedera cerebral lanjut, salah satu program rehabilitasi yang dapat diberikan pada pasien stroke yaitu mobilisasi persendian dengan latihan range of motion (Anggriani, Zulkarnain, Sulaiman, 2018). Stroke juga sering terjadi pada lanjut usia disebabkan a faktor postur tubuh dan keseimbangan lansia yang tidak normal sehingga terjadi resiko jatuh dan mengakibatkan stroke (Sulaiman \& Anggriani, 2018)

Range Of Motion (ROM) adalah batas atau besarnya gerakan sendi baik dan normal. ROM juga di gunakan sebagai dasar untuk menetapkan adanya kelainan batas gerakan sendi abnormal(Zairin Noor Helmi, 2011). Rentang gerak atau (Range Of Motion) adalah jumlah pergerakan maksimum yang dapat di lakukan pada sendi, di salah satu dari tiga bidang yaitu: sagital, frontal, atau transversal (Perry's; \& Potter, 2012). Berdasarkan gambaran diatas, peneliti tertarik untuk meneliti "Efektivitas Latihan Range of Motion terhadap Kekuatan Otot pada Pasien Stroke di RSU Siti Hajar Medan.

\section{METODE PENELITIAN}


Journal of Healthcare Technology and Medicine Vol. 6 No. 2 Oktober 2020

Universitas Ubudiyah Indonesia

e-ISSN : 2615-109X

Jenis penelitian ini adalah quasi-eksperiment, dengan menggunakan pendekatan "one group pretes and posttest design". Intervensi yang dilakukan adalah latihan ROM (Range of Motion). Populasi dalam penelitian ini adalah semua pasien stroke yang mengalami penurunan tingkat kemandirian activity daily living sebanyak 35 pasien dari 4 bulan terakhir di RSU Siti Hajar Medan.

Teknik pengambilan sampel yang digunakan pendekatan purposive sampling quasi experimental dengan pendekatan one group pre test-post test. Pada desain penelitian ini hanya terdapat satu kelompok, yaitu kelompok perlakuan sekaligus menjadi kelompok kontrol. Kelompok tersebut dilakukan intervensi berupa inkulis : pasien stroke yang berumur antara 30 tahun keatas; (b) Pasien stroke dengan iskemia yang mengalami penurunan tingkat kemandirian activity daily living. dengan tingkat ketergantungan sedang sampai berat. Kriteria Eksklusi: (a) Pasien stroke yang menggunakan terapi alternatif lain; (b) Pasien stroke dengan imobilitas (fraktur) dan gout terminal (bengkak). Besar sampel sebanyak 20 pasien stroke.

Penelitian ini menggunakan nilai alpha sebesar 0,05 atau 5\% dan tingkat kepercayaan penelitian ini 95\% (Sugiyono, 2015).latihan ROM pasif menggunakan metode langsung. Dilakukan penilaian untuk mengetahui kekuatan otot sebelum intervensi (pre-test).

\section{HASIL DAN PEMBAHASAN}

1. Karakterisitk Responden Beradasarkan Usia

Tabel 1. Karakterisitk Responden Beradasarkan Usia

\begin{tabular}{ccc}
\hline Usia & Frekuensi & Persentase (\%) \\
\hline $30-40$ & 3 & 15 \\
$41-50$ & 3 & 15 \\
$51-60$ & 10 & 50 \\
$60-70$ & 4 & 20 \\
\hline Total & $\mathbf{2 0}$ & $\mathbf{1 0 0}$ \\
\hline
\end{tabular}

Hasil penelitian menunjukkan sebagian besar responden berusia 51 sampai 60 tahun yaitu sebanyak 10 orang (50\%).

2. Karakterisitk Responden Beradasarkan Jenis Kelamin ( $=20)$ 
Journal of Healthcare Technology and Medicine Vol. 6 No. 2 Oktober 2020

Universitas Ubudiyah Indonesia

e-ISSN : 2615-109X

Tabel 2. Karakterisitk Responden Beradasarkan Jenis Kelamin ( $\mathrm{n}=20)$

\begin{tabular}{ccc}
\hline Jenis kelamin & Frekuensi & Persentase (\%) \\
\hline Laki-laki & 12 & 60 \\
Perempuan & 8 & 40 \\
\hline Total & $\mathbf{2 0}$ & $\mathbf{1 0 0}$ \\
\hline Besar responden berjenis kelamin & laki- laki sebanyak 12 orang & $(60 \%)$, perempuan
\end{tabular}
sebanyak 8 orang $(40 \%)$.

3. Kekuatan Otot Responden Sebelum dilakukan intervensi

Tabel 3. Kekuatan Otot Responden Sebelum dilakukan Intervensi

\begin{tabular}{|c|c|c|}
\hline Pre test & Frekuensi & Persentasi (\%) \\
\hline 0 & 1 & 5 \\
\hline 1 & 8 & 40 \\
\hline 2 & 2 & 10 \\
\hline 3 & 8 & 40 \\
\hline 4 & 1 & 5 \\
\hline Total & 20 & 100 \\
\hline
\end{tabular}

4. Kekuatan Otot Responden sesudah dilakukan intervensi

Tabel 4. Kekuatan Otot Responden sesudah dilakukan intervensi

\begin{tabular}{|c|c|c|}
\hline Post test & Frekuensi & Persentasi (\%) \\
\hline 1 & 1 & 5 \\
\hline 2 & 3 & 15 \\
\hline 3 & 5 & 25 \\
\hline 4 & 3 & 15 \\
\hline 5 & 8 & 40 \\
\hline Total & 20 & 100 \\
\hline
\end{tabular}


Journal of Healthcare Technology and Medicine Vol. 6 No. 2 Oktober 2020

Universitas Ubudiyah Indonesia

e-ISSN : 2615-109X

5. Nilai statistik Kekuatan Otot Responden sebelum dan sesudah dilakukan intervensi $(n=20)$

Tabel 5. Nilai statistik Kekuatan Otot Responden sebelum dan sesudah dilakukan intervensi

\begin{tabular}{cccc}
\hline Statistik & Pre-test & Post-test & Peningkatan \\
\hline Mean & 2 & 3.80 & 1.80 \\
Median & 2 & 5 & 3 \\
S. deviasi & 1.124 & 1.305 & 0.181 \\
\hline
\end{tabular}

Hasil penelitian menunjukkan rata-rata (mean) peningkatan kekuatan otot antara sebelum dan 7 hari sesudah diberikan intervensi sebesar 1,80. Terjadinya peningkatan kekuatan otot dapat mengaktifkan gerakan volunter, dimana gerakan volunter terjadi adanya transfer impuls elektrik dari girus presentalis ke korda spinalis melalui neurotransmiter yang mencapai ke otot dan menstimulasi otot sehingga menyebabkan pergerakan (Perry’s; \& Potter, 2012)

\section{Hubungan Karakteristik Usia Responden Dengan Kejadian Stroke}

Hasil penelitian menunjukkan sebagian besar responden berusia 51 sampai 60 tahun yaitu sebanyak 10 orang (50\%). Seseorang menderita stroke karena memiliki faktor risiko stroke. Usia dikategorikan sebagai faktor risiko yang tidak dapat diubah. Semakin tua usia seseorang akan semakin mudah terkena stroke Insiden stroke meningkat seiring dengan bertambahnya usia. Setelah usia 55 tahun risiko stroke iskemik meningkat 2 kali lipat tiap dekade. Prevalensi meningkat sesuai dengan kelompok usia yaitu 0,8\% pada kelompok usia 18 sampai 44 tahun, 2,7\% pada kelompok usia 45 sampai 64 tahun, dan 8,1\% pada kelompok usia 65 tahun (Rizaldy Pinzon, 2010).

\section{Hubungan Karakteristik Jenis Kelamin Responden Dengan Kejadian Stroke}

Besar responden berjenis kelamin laki- laki sebanyak 12 orang (60\%). Hasil tersebut didukung oleh Junaidi (2008, hlm.9) dan Pinzon et. al. (2010, hlm.5), bahwa laki-laki cenderung lebih tinggi untuk terkena stroke dibandingkan wanita, dengan perbandingan 1,3:1. Jenis kelamin merupakan salah satu faktor risiko terjadinya stroke, selain faktor-faktor tambahan lainnya yang dapat terjadinya stroke. Jenis kelamin laki-laki mudah terkena stroke. Hal ini dikarenakan lebih tingginya angka kejadian faktor risiko stroke (misalnya hipertensi) pada laki- 
Journal of Healthcare Technology and Medicine Vol. 6 No. 2 Oktober 2020

Universitas Ubudiyah Indonesia

e-ISSN : 2615-109X

laki (Rizaldy Pinzon, 2010). Begitu juga penelitian lainnya yang menyatakan bahwa dari jenis kelamin laki-laki usia dia atas 55 tahun lebih rentan terkena serangan stroke sebanyak 55,4\% dibandikan jenis kelamin perempuan dari 85 sampel (Sofyan, Sihombing, \& Hamra, 2012). Hasil penelitian ini sesuai dengan teori yang mengungkapkan bahwa serangan stroke lebih banyak terjadi pada laki-laki dibandingkan perempuan (Ipaenin, 2018).

\section{Hubungan Latihan Range of Motion dengan Kekeuatan Otot Pasien Stroke}

Hasil penelitian menunjukkan rata-rata (mean) peningkatan kekuatan otot antara sebelum dan 7 hari sesudah diberikan intervensi sebesar 1,80. Terjadinya peningkatan kekuatan otot dapat mengaktifkan gerakan volunter.Range Of Motion (ROM) adalah latihan yang dilakukan untuk mempertahankan atau memperbaiki tingkat kesempurnaan kemampuan menggerakkan persendian secara normal dan lengkap untuk meningkatkan massa otot dan tonus otot (Perry's; \& Potter, 2012).

Latihan Range Of Motion memiliki pengaruh terhadap rentang gerak responden bila dilakukan dengan frekuensi dua kali sehari dalam enam hari dan dengan waktu 10-15 menit dalam sekali latihan (Chaidir Reny, 2014). Memperbaiki fungsi saraf merupakan tujuan perawatan suportif dini melalui terapi fisik. ROM merupakan pergerakan persendian sesuai dengan gerakan yang memungkinkan terjadinya kontraksi dan pergerakan otot baik secara pasif maupun aktif (Perry's; \& Potter, 2012).

\section{KESIMPULAN}

Berdasarkan hasil penelitian yang sudah dilakukan pada 20 responden penderita stroke yang dirawat inap di RSU Siti Hajar dapat diambil kesimpulan sebagai berikut :

1. Terdapat peningkatan otot sesudah dilakukan intervensi sebesar 1.80 , sedangakan terjadi kekuatan otot sampai dengan kondisi 5 (normal) setelah dilakukan intervensi sebanyak 40\%.

2. Latihan ROM sangat efektif untuk meningkatkan kekuatan otot bagi pasien

\section{DAFTAR PUSTAKA}

Anggriani, Zulkarnain, Sulaiman, R. G. (2018). Pengaruh ROM ( Range of Motion ) Terhadap Kekuatan Otot Ekstremitas Pada Pasien Stoke Non Hemoragic, 3(2), 64-72. Retrieved from https://jurnal.kesdammedan.ac.id/index.php/jurhesti/article/view/46 
Chaidir Reny, Z. M. I. (2014). Dengan Bola Karet Terhadap Kekuatan Otot Pasien Stroke Non Hemoragi Di Ruang Rawat Stroke Rssn Bukittinggi Tahun 2012. Afiyah, 1(1), 1-6. Retrieved from http://ejournal.stikesyarsi.ac.id/index.php/JAV1N1/article/viewFile/3/163

Ipaenin, R. (2018). Hubungan dukungan keluarga terhadap motivasi pasien pasca stroke selama menjalani latihan fisioterapi di RS PKU Muhamadiyah Gamping Yogyakarta. Retrieved from http://eprints.ums.ac.id/25264/

Irfan, M. (2010). Fisioterapi Pada Insan Stroke. Jakarta: Graha Ilmu.

Perry's;, \& Potter. (2012). Fundamentals of Nursing - AUS Version. (4th ed.). Autralia, New Zealand: Elsevier Inc.

Rizaldy Pinzon, L. A. (2010). AWAS STROKE! Pengertian, Gejala, Tindakan, Perawatan dan Pencegahan (1st ed.). Jakarta: Andi Publiser.

Sofyan, A. M., Sihombing, I. Y., \& Hamra, Y. (2012). Hubungan Umur, Jenis Kelamin, dan Hipertensi dengan Kejadian Stroke. Medula, 1(1), 24-30.

Sugiyono. (2015). Metode Penelitian Pendidikan. Pendekatan Kuantitatif dan Kualitatif, dan R \$ D. Bandung: Alfabeta.

SUlAiMAN, S., \& ANGGRIANI, A. (2019). Sosialisasi Pencegahan Kasus Stroke Pada Lanjut Usia Di Desa Hamparan Perak Kecamatan. Amaliah: Jurnal Pengabdian Kepada Masyarakat, 1(2), 70-74. https://doi.org/10.32696/ajpkm.v1i2.193

Sulaiman, \& Anggriani. (2018). Efek Postur Tubuh Terhadap Keseimbangan Lanjut Usia Di Desa Suka Raya Kecamatan Pancur Batu. Jurnal JUMANTIK, 3(2), 127-140. Retrieved from http://jurnal.uinsu.ac.id/index.php/kesmas/article/view/2875/1714

Word Health Organization. (2014). World Health Statistics. WHO Library Cataloguing-inPublication Data (Vol. 19). Amerika Serikat: WHO Library Cataloguing-in-Publication Data. https://doi.org/10.1177/1742766510373715

Zairin Noor Helmi. (2011). BUKU AJAR GANGGUAN MUSKULOSKELETAL. Salemba Medika 